Perspectives in Inflammation 
Under the Patronage of H.R.H. The Duchess of Kent

Proceedings of an International Meeting on Future Trends in Inflammation III

Organized by The European Biological Research Association

Under the auspices of

The Arthritis \& Rheumatism Council

The British Pharmacological Society

The British Society of Immunology

The European League Against Rheumatism

The Pathological Society of Great Britain \& Ireland

The Royal Society of Medicine

Held at the Grosvenor House Hotel, Park Lane, London, February 14th-18th, 1977 


\section{Perspectives in Inflammation}

\section{Future Trends and Developments}

The Proceedings of the Third International Meeting on Future Trends in Inflammation organized by the European Biological Research Association and held in London, February 14th-18th, 1977

Edited by

D. A. Willoughby

Professor, Department of Experimental Pathology and Rheumatology, St. Bartholomew's Hospital, London

J. P. Giroud

Professor, Department of Pharmacology, Hôpital Côchin, Paris

G. P. Velo

Professor, Department of Pharmacology, Policlinico Borgo, 


\author{
Published by \\ MTP Press Limited \\ PO Box 55, St. Leonard's House \\ St. Leonardgate, LANCASTER, England \\ Copyright (C) 1977 MTP Press Limited \\ Softcover reprint of the hardcover 1st edition 1977
}

First published 1977

No part of this book may be reproduced

in any form without permission from the

publisher except for the quotation of

brief passages for the purpose of review

ISBN 978-94-011-7187-8

ISBN 978-94-011-7185-4 (eBook)

DOI $10.1007 / 978-94-011-7185-4$ 


\section{Contents}

Preface

xiii

List of Contributors

XV

SECTION I IMMUNOLOGICAL ASPECTS OF INFLAMMATION

Chairman: J. L. Turk; Co-Chairman: G. A Voisin

Co-Chairman's Introductory Remarks-Immunostimulation and immunosuppression of what?

Guy André Voisin

1. The rationale of using levamisole in the treatment of rheumatoid arthritis

J. Symoens

2. Immunostimulation, levamisole and rheumatoid arthritis

E. C. Huskisson

3. The effect of cytotoxic drugs on the formation of mononuclear phagocytes

R. L. Souhami, J. W. B. Bradfield, N. E. Parker

4. Rheumatoid factor-immunoglobulin $\mathrm{G}$ complex precipitation and neutrophil stimulation: an in vitro model for rheumatoid inflammation

R. Turner, H. Mashburn, R. Collins, L. DeChatelet,

J. Kaufmann

Chairman's Summing-up and Future Trends-Immunological aspects of inflammation - the network of interactions

J. L. Turk 


\section{PERSPECTIVES IN INFLAMMATION}

SECTION II CHRONIC INFLAMMATION: CELLULAR EVENTS

Chairman: A. C. Allison; Co-Chairman: P. C. Wilkinson

Co-Chairman's Introductory Remarks-Cellular mechanisms in chronic inflammation

P. C. Wilkinson

5. A model for assessing effects of drugs on granulocyte emigration in vivo

J. F. Borel, Camille Feurer

6. A polymorph abnormality in Crohn's disease

G. Loewi, A. Segal, P. Tooth

7. The origin and kinetics of liver macrophages during steady state and inflammation (Abstract)

R. van Furth, R. W. Crofton

8. Lymphocyte-mediated eosinophilia in guinea pigs with delayed hypersensitivity to a chemical

W. E. Parrish, E. Luckhurst

9. A role for L-lymphocytes in chronic inflammation

David A. Horwitz

10. Cartilage degradation by macrophages, fibroblasts and synovial cells in culture. An in vitro model suitable for studies on rheumatoid arthritis

G. Vaes, P. Hauser, G. Huybrechts-Godin, C. Peeters-Joris

11. Adjuvant arthritis: immune responses and effects of Tilorone or interferon in partially suppressing the disease

Carl M. Pearson, Yi-Han Chang

General Discussion

Chairman's Summing-up and Future Trends-Cellular reactions in inflammation
A. C. Allison

SECTION III CHRONIC INFLAMMATION: MECHANISMS

Chairman: L. E. Glynn; Co-Chairman: I. Ginsburg

Co-Chairman's Introductory Remarks-The role played by leukocyte extracts and inflammatory exudates in the release of lipopolysaccharides from Gram negative bacteria: relation to tissue damage induced during infections

I. Ginsberg, Z. Duchan, S. Bergner-Rabinowitz, M. Ferne 


\section{CONTENTS}

12. The effect of local elevation of leukocyte cyclic AMP content on lysosomal enzyme release during acute inflammation in vivo

D. A. Deporter

13. Recent studies on the secretory activity of mononuclear phagocytes with special reference to prostaglandins

P. Davies, R. J. Bonney, M. E. Dahlgren, L. Pelus,

F. A. Kuehl, Jr., J. L. Humes

14. Interactions of macrophages and complement components in the pathogenesis of chronic inflammation

H. U. Schorlemmer, J. Ferluga, A. C. Allison

15. Matrix vesicles and apatite nodules in arthritic cartilage

S. Yousuf Ali

16. Crystal induced inflammation and osteoarthritis

P. A. Dieppe

17. Microanalysis of particulate material involved in inflammation

P. A. Dieppe, P. R. Crocker, D. A. Willoughby

18. The influence of chemical composition of plasma membranes on the functional activities of macrophages

M. Dianzani, F. Feo, R. A. Canuto, R. Garcea, L. Gabriel, M. V. Torrielli

Opening to Discussion-Mechanisms in chronic inflammation

A. Cats

General Discussion

Chairman's Summing-up and Future Trends

L. E. Glynn

SECTION IV GENERAL ASPECTS I

Chairman: J. P. Giroud, Co-Chairman: K. Brune

19. Dual function of E-type prostaglandins in models of chronic inflammation

I. L. Bonta, M. J. Parnham, M. J. P. Adolfs, L. van Vliet

20. Interactions between prostaglandin $\mathrm{E}$ and cyclic nucleotides in chronic inflammatory disease

M. J. Parnham, I. L. Bonta, M. J. P. Adolfs

21. The time course of the vascular events associated with inflammation due to ultraviolet irradiation of guinea pig ears

D. F. Woodward, D. A. A. Owen 


\section{PERSPECTIVES IN INFLAMMATION}

22. Role of macrophages in D-penicillamine-induced stimulation of DNA synthesis in lymph node cells in vitro

E. Arrigoni-Martelli, L. Binderup, E. Bramm

23. Anti-inflammatory effects of tumour bearing

S. Norman, E. Sorkin

24. Role of platelets and of prostaglandin synthetase on hypotensive effects of arachidonic acid and of carrageenan

Bernardo B. Vargaftig, Jean Lefort

25. Evidence for a pivotal role of the endoperoxide, $\mathrm{PGG}_{2}$, in inflammatory processes

F. A. Kuehl, Jr., J. L. Humes, R. W. Egan

26. Thiols and prostaglandin biosynthesis

C. Deby, Z. M. Bacq, P. van Caneghem

27. Interactions of non-steroidal anti-inflammatory drugs with substance P-like and gastrointestinal hormones-like polypeptides

J. P. Famaey, J. Fontaine, J. Reuse

28. Salicylic acid and proquazone: the differences in absorption and biodistribution explain their different profile of side-effects

Alain Schweitzer, Kay Brune

29. Degradation of bovine nasal cartilage by a neutral protease from human leukocyte granules

D. Kruze, P. Salgam, K. Fehr, A. Boni

30. Inhibition of experimental ocular inflammation by topical application of non-steroidal anti-inflammatory drugs (NSAID)

P. Gautheron, Ph. Conquet, J. C. LeDouarec

31. Potentiation of acenocoumarin-induced anticoagulation by a new anti-inflammatory agent in man (Abstract)

I. Caruso, M. Fumagalli, F. Montrone, M. B. Donati,

R. Latini, G. Bianchetti, L. Carratelli

32. In vitro methods for assessing anti-inflammatory drug activity (Abstract)

A. Tursi, M. P. Loria, G. Specchia, L. Bonomo

SECTION V GENERAL ASPECTS II

Chairman: G. P. Velo; Co-Chairman: J. Sondergaard

33. Potentiation of antibody formation by proteases in vitro

Thomas L. Vischer 


\section{CONTENTS}

- 34. Triggers of prostaglandin release from macrophages Marcus Glatt, Käthy Wagner, Kay Brune

35. Biological, chemical and pharmacological induction of the properdin-mediated pathway of complement activation in vitro

T. Di Perri, A. Auteri, F. Laghi Pasini, F. Mattioli

36. Immune reactions of lymphocytes eluted from rheumatoid inflammatory tissue

T. G. Abrahamsen, S. S. Frфhland, J. B. Natvig, J. Pahle

37. Attempts at producing immune complexes in vitro between isolated macroglobulins and purified IgGs

Nanna Svartz

38. Behaviour of some inflammation parameters in plasma and synovial fluid in some rheumatic diseases (Abstract)

R. Numo, V. Pipitone

39. Some applications of quantitative two-dimensional immunoelectrophoresis in the study of the systemic acute-phase reaction of the rat

R. Scherer, M. Abd-el-Fattah, G. Ruhenstroth-Bauer

40. Restoration of the neutrophil chemotactic responsiveness by levamisole treatment in patients with recurrent infections, eczema and hyperimmunoglobulinaemia $\mathrm{E}$

R. S. Weening, Liesbeth Stricker, D. Roos, J. L. Molenaar,

L. J. Dooren, R. K. B. Schuurman

41. Rheumatoid-like joint lesions in rabbits injected intravenously with foreign serum

A. R. Poole, R. R. A. Coombs

- 42. Anti-inflammatory activity of some bacterial immunostimulants.

Relation with macrophage migration

P. Lallouette, A. Schwartz

43. Inflammatory exudates and mitogenic activity

M. Adolphe, J. Fontagne, M. Pelletier, D. Blondelon,

P. Lechat, J, P. Giroud

44. Secretory activity of epithelioid cells

N. Mokhtar, W. G. Spector

45. Vascular changes during acute inflammatory responses in rat hindpaws

D. A. A. Owen 


\section{PERSPECTIVES IN INFLAMMATION}

SECTION VI PHARMACOLOGICAL ASPECTS: ANIMAL/MAN

Chairman: C. M. Pearson

46. Activators and inhibitors of fibrinolysis in rheumatoid joint inflammation

L. B. A. van de Putte, C. Kluft, V. Noordhoek Hegt,

G. Wijngaards, F. Haverkate, A. Cats

47. Relationships between increased vascular permeability, oedema, hyperalgesia and the effect of non-steroid anti-inflammatory drugs

S. H. Ferreira, Maria Teresinha Zanin, Berenice B. Lorenzetti

48. Two sites of action of steroids on the prostaglandin system G. P. Lewis, P. J. Piper

49. Studies on the clinical and laboratory pharmacology of drug formulations of bovine $\mathrm{Cu}-\mathrm{Zn}$ superoxide dismutases (orgotein)

W. Huber, K. B. Menander-Huber, M. G. P. Saifer, P. H-C. Dang

50. Humoral control of monocytopoiesis (Abstract)

D. van Waarde, E. Hulsing-Hesselink

General Discussion

Chairman's Summing-up and Future Trends

C. M. Pearson

SECTION VII PHARMACOLOGICAL ASPECTS: MAN/ANIMAL

Chairman: D. A. Willoughby; Co-Chairman: P. Franchimont

Co-Chairman's Opening Remarks

P. Franchimont, G. Heynen

51. Difficulties in the clinical evaluation of new anti-inflammatory drugs

G. Katona

52. Is the mechanism of action during treatment of rheumatoid arthritis with penicillamine and gold thiomalate the same?

Egil Jellum, Eimar Munthe

53. About immunological anomalies in treated and non-treated rheumatoid arthritis: rosette test and immunofluorescence of B-cells

H. Roux, P. Mercier, Y. Jeandel, M. T. Gabriel-Brouillet,

G. Serratrice 


\section{CONTENTS}

54. Should penicillamine be prescribed for rheumatoid arthritis?

W. H. Lyle

55. Long-term evaluation of intermittent levamisole treatment in rheumatoid arthritis

E. M. Veys, H. Mielants

General Discussion

Closing Remarks

D. A. Willoughby

POSTER SESSIONS 


\section{Preface}

This report on Future Trends in Inflammation III is the record of what is now firmly established as a series of multidisciplinary meetings organized by the European Biological Research Association. The aim of these meetings is to provide a forum for free exchange of information between basic scientists of many disciplines and clinicians to provide better understanding of problems of common interest. The next major meeting will be held in 1980.*

The European Biological Research Association promotes scientific and clinical collaboration among the member countries of the EEC. It encourages exchange of information between scientists and clinicians from centres all over the world. In addition to the major international meetings small workshops are organized on specific problems of common interest.

Once again the Editors have attempted to capture the spirit of the meeting by publishing 'verbatim' the discussion. It can be seen that the discussions were exciting and formed an important part of the meeting.

It is possible that inaccuracies have crept into the discussions; if so we apologize. It was decided that the proceedings of such a meeting had maximum value with rapid publication.

We would like to thank the participants for the enthusiasm and goodwill which persisted throughout the meeting both scientifically and socially.

Above all we wish to thank H.R.H. The Duchess of Kent for acting as Patron of this meeting.

D. A. Willoughby

J. P. Giroud

G. P. Velo

* For further information regarding the 1980 meeting please contact Professor D. A. Willoughby of Department of Experimental Pathology, St. Bartholomew's Hospital, London, EC1A 7BE, England. 


\section{List of Contributors}

JAN AASETH

Institute of Clinical Biochemistry, Rikhospitalet. Oslo, 1, Norway

\section{ABD-EL-FATTAH}

Department of Biochemistry, Faculty of Science, Ain Sams University, Cairo, Egypt

\section{T. G. ABRAHAMSEN}

Institute of Immunology and

Rheumatology, Rikhospitalet, Oslo 1, Norway

\section{J. P. ADOLFS}

Department of Pharmacology, Faculty of Medicine, Erasmus University,

Rotterdam, The Netherlands

\section{ADOLPHE}

Laboratory of Cellular Pharmacology, College for Advanced Studies, Centre de Recherches de l'Association Claude Bernard, F-75006 Paris, France

\section{S. YOUSUF ALI}

Experimental Pathology Unit, Institute of Orthopaedics, University of London, Royal National Orthopaedic Hospital, Stanmore, Middlesex, HA7 4LP

\section{A. C. ALLISON}

MRC Clinical Research Centre, Harrow, Middlesex, HA1 3UJ

\section{E. ARRIGONI-MARTELLI \\ Department of Pharmacology, Leo Pharmaceutical Products, DK-2750 Ballerup, Denmark}

\section{A. AUTERI}

Institute of Medical Semeiotics, School of Medicine, University of Sienna, Italy

\section{Z. M. BACQ}

Applied Biochemistry Laboratory,
University of Liege, B-4020 Liege, Belgium

\section{S. BERGNER-RABINOWITZ}

The Department of Oral Biology, Hadassah School of Medicine, The Hebrew University, Jerusalem, Israel

\section{G. BIANCHETTI}

Rheumatology Service, L. Sacco Hospital, Milan, Italy

\section{BINDERUP}

Department of Pharmacology, Leo Pharmaceutical Products, DK-2750 Ballerup, Denmark

\section{BLANDELON}

Laboratory of Cellular Pharmacology, College for Advanced Studies, Centre de Recherches de l'Association Claude Bernard, F-75006 Paris, France

\section{A. BÖNI}

Department of Rheumatology, University of Zurich, Cantonal Hospital, CH-8091 Zurich, Switzerland

\section{R. J. BONNEY}

Merck Institute for Therapeutic Research, Rahway, New Jersey 07065, USA

\section{BONOMO}

Institute of Clinical Medicine II, University of Bari, Policlinico, I-70124, Bari, Italy

\section{L. BONTA}

Department of Pharmacology, Faculty of Medicine, Erasmus University, Rotterdsm, The Netherlands

\section{J. F. BOREL}

Biological and Medical Research 


\section{PERSPECTIVES IN INFLAMMATION}

Division, Sandoz Ltd., CH-4002 Basel, Switzerland

\section{J. W. D. BRADFIELD}

Department of Experimental Pathology, St. Mary's Hospital Medical School, London, W.2

\section{E. BRAMM}

Department of Pathology, Leo

Pharmaceutical Products, DK-2750

Ballerup, Denmark

\section{K. BRUNE}

University of Basel, CH-4056 Basel, Switzerland

P. van CANEGHEM

Applied Biochemistry Laboratory, University of Liege, B-4020 Liege, Belgium

\section{R. A. CANUTO}

Institute of General Pathology, University of Turin, I-10125 Turin, Italy

\section{CARRATELLI}

Merck Sharp and Dohme (Italia) S.p.a., I-00191 Rome, Italy

\section{CARUSO}

Rheumatology Service. L. Sacco Hospital, Milan, Italy

\section{A. CATS}

Department of Rheumatology, University Hospital, Leiden, The Netherlands

\section{Y.-H. CHANG}

Division of Rheumatology, Department of Medicine, UCLA School of Medicine, Los Angeles, California 90024, USA

\section{DeCHATELET}

Department of Biochemistry, The Bowman Gray School of Medicine, Wake Forest University, Winston-Salem, North Carolina 27103, USA

\section{R. COLLINS}

Department of Biochemistry, The Bowman Gray School of Medicine, Wake Forest University, Winston-Salem, North Carolina 27103, USA

\section{Ph. CONQUET}

MSD-Chibret Research Institute, F-63018 Clermont-Ferrand, France

\section{R. R. A. COOMBS}

Division of Immunology, Department of Pathology, University of Cambridge

\section{P. R. CROCKER}

Department of Rheumatology and

Experimental Pathology, St.

Bartholomew's Hospital, London, E.C.1

\section{R. W. CROFTON}

Department of Infectious Diseases, University Hospital, Leiden, The Netherlands

\section{E. DAHLGREN}

Merck Institute for Therapeutic Research, Rahway, New Jersey 07065, USA

\section{P. H.-C. DANG}

Diagnostic Data Inc., Mountain View, California 94043, USA

\section{P. DAVIES}

Merck Institute for Therpeutic Research, Rahway, New Jersey 07065, USA

\section{DEBY}

Applied Biochemistry Laboratory, University of Liege, B-4020 Liege, Belgium

\section{A. DEPORTER}

Faculty of Dentistry, University of Toronto, Toronto, Canada

\section{DIANZANI}

Institute of General Pathology,

University of Turin, I-10125 Turin, Italy

\section{P. A. DIEPPE}

Department of Rheumatology and Experimental Pathology, St.

Bartholomew's Hospital, London, E.C.1

\section{B. DONATI}

Rheumatology Service, L. Sacco Hospital, Milan, Italy

\section{J. DOOREN}

Department of Paediatrics, University Hospital, Leiden, The Netherlands

\section{J. C. LeDOUAREC}

MSD-Chibret Research Institute, F-63018

Clermont-Ferrand, France 


\section{LIST OF CONTRIBUTORS}

\section{Z. DUCHAN}

The Department of Oral Biology, Hadassah School of Medicine, The Hebrew University, Jerusalem, Israel

\section{R. W. EGAN}

Merck Institute for Therapeutic Research, Rahway, New Jersey 07065, USA

\section{J. P. FAMAEY}

Laboratory of Pharmacology, Rheumatology Unit, School of Medicine, University of Brussels, B-1000 Brussels, Belgium

\section{K. FEHR}

Department of Rheumatology, University of Zurich, Cantonal Hospital, CH-8091 Zurich, Switzerland

\section{F. FEO}

Institute of General Pathology, University of Turin, I-10125 Turin, Italy

\section{J. FERLUGA}

Institute of Medical Microbiology, Johannes Gutenberg University, D-6500 Mainz, West Germany

\section{FERNE}

The Department of Oral Biology, Hadassah Medical School, The Hebrew University, Jerusalem, Israel

\section{S. H. FERREIRA}

Department of Pharmacology, Faculty of Medicine, University of Sao Paulo, Sao Paulo, Brazil

\section{CAMILLE FEURER}

Biological and Medical Research Division, Sandoz Ltd., CH-4002 Basel, Switzerland

\section{J. FONTAGNE}

Laboratory of Cellular Pharmacology, College for Advanced Studies, Centre de Recherches de l'Association Claude Bernard, F-75006 Paris, France

\section{J. FONTAINE}

Laboratory of Pharmacology,

Rheumatology Unit, School of Medicine, University of Brussels, B-1000 Brussels, Belgium

\section{P. FRANCHIMONT}

Radioimmunology Laboratory, University of Liege, B-4000 Liege, Belgium

\section{S. S. FR $\phi$ HLAND}

Institute of Immunology and

Rheumatology, Rikshospitalet, Oslo 1, Norway

\section{FUMGALLI}

Rheumatology Service, L. Sacco Hospital, Milan, Italy

\section{R. van FURTH}

Department of Infectious Diseases, University Hospital, Leiden, The Netherlands

\section{GABRIEL}

Institute of General Pathology, University of Turin, I-10125 Turin, Italy

\section{T. GABRIEL-BROUILLET}

Rheumatology Clinic, C.H.U. Tirrone, Marseilles, France

\section{R. GARCEA}

Institute of General Pathology, University of Turin, I-10125 Turin, Italy

\section{P. GAUTHERON}

MSD-Chibret Research Institute, F-63018 Clermont-Ferrand, France

\section{GINSBURG}

The Department of Oral Biology, Hadassah School of Medicine, The Hebrew University, Jerusalem, Israel

\section{J. P. GIROUD}

Department of Pharmacology, Hospital Cochin, Paris 14, France

\section{GLATT}

Department of Pharmacology, University of Basel, CH-4056 Basel, Switzerland

\section{E. GLYNN}

Kennedy Institute of Rheumatology, Hammersmith, London W6 7DW

\section{P. HAUSER}

Laboratory of Physiological Chemistry, University of Leuven, Leuven, Belgium 


\section{PERSPECTIVES IN INFLAMMATION}

\section{F. HAVERKATE}

Gaubius Institute, Health Research Organization TNO, Leiden, The Netherlands

\section{G. HEYNEN}

Radioimmunology Laboratory, University of Liege, B-4000 Liege, Belgium

\section{A. HOROWITZ}

Division of Rheumatology, Department of Internal Medicine, University of Virginia School of Medicine, Charlottesville, Virginia 22901, USA

\section{W. HUBER}

Diagnostic Data Inc., Mountain View, California 94043, USA

\section{E. HULSING-HESSELINK}

Department of Infectious Diseases, University Hospital, Leiden, The Netherlands

\section{J. L. HUMES}

Merck Institute for Therapeutic Research, Rahway, New Jersey 07065, USA

\section{E. C. HUSKISSON}

St. Bartholomew's Hospital, London

\section{G. HUYBRECHT-GODIN}

Laboratory of Physiological Chemistry, University of Leuven, Leuven, Belguim

\section{Y. JEANDEL}

Rheumatology Clinic, C.H.U. Tirrone, Marseilles, France

\section{E. JELLUM}

Institute of Clinical Biochemistry, Rikshospitalet, Oslo 1, Norway

\section{G. KATONA}

Rheumatology Service, General Hospital, Mexico City, Mexico, D. F.

\section{J. KAUFMANN}

Department of Biochemistry, The Bowman Gray School of Medicine, Wake Forest University, Winston-Salem, North Carolina 27103, USA

\section{KLUFT}

Department of Rheumatology, University Hospital, Leiden, The Netherlands

\section{KRUZE}

Department of Rheumatology, University of Zurich, Cantonal Hospital, CH-8091 Zurich, Switzerland

F. A. KUEHL, Jr.

Merck Institute for Therapeutic Research, Rahway, New Jersey 07065, USA

\section{P. LALLOUETTE}

41, rue Camille Pelletan, F-92305

Levallois-Perret, France

\section{R. LATINI}

Rheumatology Service, L. Sacco Hospital, Milan, Italy

\section{P. LECHAT}

Laboratory of Cellular Pharmacology, College for Advanced Studies, Centre de Recherches de l'Association Claude Bernard, F-75006 Paris, France

\section{J. LEFORT}

Centre de Recherches Merrell International F-67084 Strasbourg, France

\section{G. P. LEWIS}

Department of Pharmacology, Royal College of Surgeons of England, London, WC2A 3PN

\section{G. LOEWI}

MRC Clinical Research Centre, Harrow, Middlesex, HA1 3UJ

\section{BERENICE B. LORENZETTI}

Department of Pharmacology, Faculty of Medicine, University of Sao Paulo, Sao Paulo, Brazil

\section{P. LORIA}

Institute of Clinical Medicine II, University of Bari, Policlinico, I-70124, Bari, Italy

\section{E. LUCKHURST}

Lister Institute of Preventive Medicine, Elstree, Herts

\section{W. H. LYLE}

Dista Products Limited, Speke, Liverpool, L24 9LN

\section{H. MASHBURN}

Department of Biochemistry, The Bowman Gray School of Medicine, Wake Forest University, Winston-Salem, North Carolina 27103, USA 


\section{LIST OF CONTRIBUTORS}

K. B. MENANDER-HUBER

Diagnostic Data Inc., Mountain View, California 94043, USA

\section{P. MERCIER}

Transfusion Centre, Marseilles, France

\section{H. MIELANTS}

Section of Rheumatology, University Hospital, B-9000 Ghent, Belgium

\section{N. MOKHTAR}

Department of Pathology, St.

Bartholomew's Hospital Medical College, London

\section{J. L. MOLENAAR}

Central Laboratory of the Netherlands' Red Cross Blood Transfusion Service, Amsterdam, The Netherlands

\section{F. MONTRONE}

Rheumatology Service, L. Sacco Hospital, Milan, Italy

\section{E. MUNTHE}

Oslo Rheumatism Hospital, Oslo 1, Norway

\section{J. B. NATVIG}

Oslo Rheumatism Hospital, Oslo 1, Norway

\section{NOORDHOEK HEGT}

Gabius Institute, Health Research Organization TNO, Leiden, The Netherlands

\section{S. NORMANN}

Department of Pathology, College of Medicine, University of Florida, Gainesville, Florida 32610, USA

\section{R. NUMO}

Rheumatology Service, University of Bari, Policlinico, I-70124 Bari, Italy

\section{A. A. OWEN}

Department of Pharmacology, The Research Institute, Smith Kline and French Laboratories Ltd., Welwyn Garden City, Herts

\section{J. PAHLE}

Oslo Rheumatism Hospital, Oslo 1, Norway

\section{W. E. PARISH}

Unilever Research, Colworth House, Sharnbrook, Bedford

\section{N. E. PARKER}

University College Hospital Medical School, London

\section{J. PARNHAM}

Department of Pharmacology, Faculty of Medicine, Erasmus University, Rotterdam, The Netherlands

\section{F. LAGHI PASINI}

Institute of Medical Semeiotics, School of Medicine, University of Sienna, Sienna, Italy

\section{M. PEARSON}

Division of Rheumatology, Department of Medicine, UCLA School of Medicine, Los Angeles, California, USA

\section{PEETERS-JORIS}

Laboratory of Physiological Chemistry, University of Leuven, Leuven, Belguim

\section{PELLETIER}

Laboratory of Cellular Pharmacology, College for Advanced Studies, Centre de Recherches de l'Association Claude Bernard, F-75006 Paris, France

\section{PELUS}

Merck Institute for Therapeutic Research, Rahway, New Jersey 07065, USA

\section{T. Di PERRI}

Institute of Medical Semeiotics, School of Medicine, University of Sienna, Sienna, Italy

P. J. PIPER

Department of Pharmacology, Royal College of Surgeons of England, London, WC2A 3PN

\section{PIPITONE}

Rheumatology Service, University of Bari, Policlinico, I-70124 Bari, Italy

\section{A. R. POOLE}

Joint Diseases Laboratory, Shriners Hospital for Crippled Children, Montreal, Quebec, H3G 1A6, Canada

L. B. A. van de PUTTE

Department of Rheumatology, University Hospital, Leiden, The Netherlands 


\section{PERSPECTIVES IN INFLAMMATION}

\section{J. REUSSE}

Laboratory of Pharmacology,

Rheumatology Unit, School of Medicine, University of Brussels, B-1000 Brussels, Belgium

\section{ROOS}

Central Laboratory of the Netherlands' Red Cross Blood Transfusion Service, Amsterdam, The Netherlands

\section{H. ROUX}

Rheumatology Clinic, C.H.U. Tirrone, Marseilles, France

\section{G. RUHENSTROTH-BAUER}

Max-Planck-Institute for Biochemistry, D-8032 Martinsried bei München, West Germany

\section{G. P. SAIFER}

Diagnostic Data Inc., Mountain View, California 94043, USA

\section{A. SEGAL}

MRC Clinical Research Centre, Harrow, Middlesex, HA1 3UJ

\section{R. SCHERER}

Max-Planck-Institute for Biochemistry, D-8032 Martinsried bei München, West Germany

\section{H. U. SCHORLEMMER}

Institute for Medical Microbiology, Johannes Gutenburg University, D-6500 Mainz, West Germany

\section{R. K. B. SCHUURMAN}

Sophia Children's Hospital, Rotterdam, The Netherlands

\section{A. SCHWARTZ}

41, rue Camille Pelleton, F-92305

Levallois-Perret, France

\section{A. SCHWEITZER}

Department of Biopharmaceutics, Sandoz AG, CH-4002 Basel, Switzerland

\section{A. SEGAL}

MRC Clinical Research Centre, Harrow Middlesex, HA1 3UJ

\section{G. SERRATRICE}

Rheumatology Clinic, C.H.U. Tirrone, Marseilles, France

\section{J. SONDERGAARD}

Department of Dermatology, Hvidovre

Hospital, Hvidovre, Denmark

\section{E. SORKIN}

Department of Medicine, Swiss Research Institute, CH-7270 Davos, Switzerland

\section{R. L. SOUHAMI}

University College Hospital Medical School, London

\section{G. SPECCHIA}

Institute of Clinical Medicine II, University of Bari Medical School, I-70124 Bari, Italy

\section{W. G. SPECTOR}

Department of Pathology, St.

Bartholomew's Medical College, London

\section{LIESBETH STRICKER}

Central Laboratory of the Netherlands' Red Cross Blood Transfusion Service, Amsterdam, The Netherlands

\section{NANNA SVARTZ}

King Gustav V Research Institute, S-10 401 Stockholm, Sweden

\section{J. SYMOENS}

Department of Clinical Research, Janssen Pharmaceutica Research Laboratories, B-2340 Beerse, Belgium

\section{P. TOOTH}

MRC Clinical Research Centre, Harrow, Middlesex, HA1 3UJ

\section{V. TORRIELLI}

Institute of General Pathology, University of Turin, I-10125 Turin, Italy

\section{J. L. TURK}

Department of Pathology, Royal College of Surgeons of England, London, WC2A 3PN

\section{R. TURNER}

Department of Medicine, The Bowman Gray School of Medicine, Wake Forest University, Winston-Salem, North Carolina 27103, USA

\section{A. TURSI}

Institute of Clinical Medicine II, University of Bari Medical School, I-70124 Bari, Italy 


\section{LIST OF CONTRIBUTORS}

\section{B. VARGAFTIG}

Centre de Recherche Merrell International, F-67084 Strasbourg, France

\section{G. VAES}

Laboratory of Physiological Chemistry, University of Leuven, Leuven, Belgium

\section{G. P. VELO}

Department of Pharmacology, Policlinico Borgo Roma, I-37100 Verona, Italy

\section{E. M. VEYS}

Rheumatology Section, University Hospital, B-9000 Ghent, Belgium

\section{T. L. VISCHER}

Department of Rheumatology, University of Geneva, Hôpital Cantonal CH-1211 Geneva, Switzerland

\section{L. van VLIET}

Department of Pharmacology, Faculty of Medicine, Erasmus University, Rotterdam, The Netherlands

\section{G. A. VOISIN}

Centre of Immuno-Pathology and Experimental Immunology, l'Association Claude Bernard, Hôpital Saint-Antoine, F-75012 Paris, France

D. van WAARDE

Department of Infectious Diseases, University Hospital, Leiden, The Netherlands

\section{KÄTHY WAGNER}

Department of Pharmacology, University of Basel, CH-4056 Basel, Switzerland

\section{R. S. WEENING}

Central Laboratory of the Netherlands' Red Cross Blood Transfusion Service, Amsterdam, The Netherlands

\section{G. WIJNGAARDS}

Gaubius Institute, Health Research Organization TNO, Leiden, The Netherlands

\section{P. C. WILKINSON}

Bacteriology and Immunology Department, University of Glasgow, Western Infirmary, Glasgow, G11 6NT

\section{A. WILLOUGHBY}

Department of Rheumatology and Experimental Pathology, St.

Bartholomew's Hospital, London, E.C.1

\section{F. WOODWARD}

Department of Pathology, The Research Institute, Smith Kline and French Laboratories Limited, Welwyn Garden City, Herts

\section{MARIA TERESINHA ZANIN}

Department of Pharmacology, Faculty of Medicine, University of Sao Paulo, Sao Paulo, Brazil 